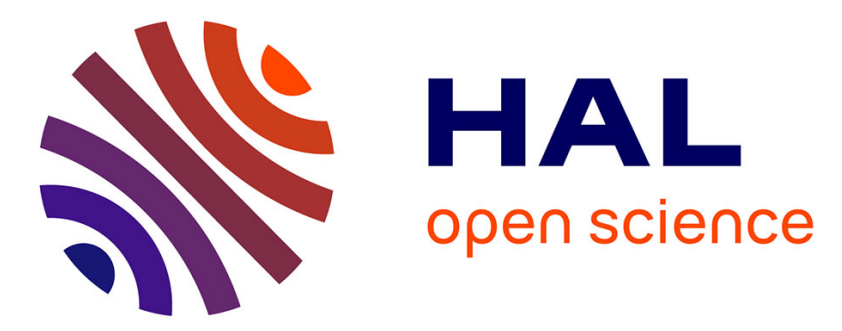

\title{
Information and Communication Technologies for Development
}

\author{
Julian M. Bass, P. J. Wall
}

\section{To cite this version:}

Julian M. Bass, P. J. Wall. Information and Communication Technologies for Development: 16th IFIP WG 9.4 International Conference on Social Implications of Computers in Developing Countries, ICT4D 2020, Manchester, UK, June 10-11, 2020, Proceedings. Springer International Publishing, AICT-587, 2020, IFIP Advances in Information and Communication Technology, 978-3-030-65827-4. 10.1007/978-3-030-65828-1 . hal-03272515

\section{HAL Id: hal-03272515 \\ https://hal.inria.fr/hal-03272515}

Submitted on 28 Jun 2021

HAL is a multi-disciplinary open access archive for the deposit and dissemination of scientific research documents, whether they are published or not. The documents may come from teaching and research institutions in France or abroad, or from public or private research centers.
L'archive ouverte pluridisciplinaire HAL, est destinée au dépôt et à la diffusion de documents scientifiques de niveau recherche, publiés ou non, émanant des établissements d'enseignement et de recherche français ou étrangers, des laboratoires publics ou privés. 


\section{IFIP Advances in Information and Communication Technology}

\section{Editor-in-Chief}

Kai Rannenberg, Goethe University Frankfurt, Germany

\section{Editorial Board Members}

TC 1 - Foundations of Computer Science

Luís Soares Barbosa (D), University of Minho, Braga, Portugal

TC 2 - Software: Theory and Practice

Michael Goedicke, University of Duisburg-Essen, Germany

TC 3 - Education

Arthur Tatnall $\mathbb{D}$, Victoria University, Melbourne, Australia

TC 5 - Information Technology Applications

Erich J. Neuhold, University of Vienna, Austria

TC 6 - Communication Systems

Burkhard Stiller, University of Zurich, Zürich, Switzerland

TC 7 - System Modeling and Optimization

Fredi Tröltzsch, TU Berlin, Germany

TC 8 - Information Systems

Jan Pries-Heje, Roskilde University, Denmark

TC 9 - ICT and Society

David Kreps (iD, University of Salford, Greater Manchester, UK

TC 10 - Computer Systems Technology

Ricardo Reis(D), Federal University of Rio Grande do Sul, Porto Alegre, Brazil

TC 11 - Security and Privacy Protection in Information Processing Systems

Steven Furnell $\mathbb{D}$, Plymouth University, UK

TC 12 - Artificial Intelligence

Eunika Mercier-Laurent $\left.{ }^{(}\right)$, University of Reims Champagne-Ardenne, Reims, France

TC 13 - Human-Computer Interaction

Marco Winckler $\mathbb{D}$, University of Nice Sophia Antipolis, France

TC 14 - Entertainment Computing

Rainer Malaka, University of Bremen, Germany 


\section{IFIP - The International Federation for Information Processing}

IFIP was founded in 1960 under the auspices of UNESCO, following the first World Computer Congress held in Paris the previous year. A federation for societies working in information processing, IFIP's aim is two-fold: to support information processing in the countries of its members and to encourage technology transfer to developing nations. As its mission statement clearly states:

IFIP is the global non-profit federation of societies of ICT professionals that aims at achieving a worldwide professional and socially responsible development and application of information and communication technologies.

IFIP is a non-profit-making organization, run almost solely by 2500 volunteers. It operates through a number of technical committees and working groups, which organize events and publications. IFIP's events range from large international open conferences to working conferences and local seminars.

The flagship event is the IFIP World Computer Congress, at which both invited and contributed papers are presented. Contributed papers are rigorously refereed and the rejection rate is high.

As with the Congress, participation in the open conferences is open to all and papers may be invited or submitted. Again, submitted papers are stringently refereed.

The working conferences are structured differently. They are usually run by a working group and attendance is generally smaller and occasionally by invitation only. Their purpose is to create an atmosphere conducive to innovation and development. Refereeing is also rigorous and papers are subjected to extensive group discussion.

Publications arising from IFIP events vary. The papers presented at the IFIP World Computer Congress and at open conferences are published as conference proceedings, while the results of the working conferences are often published as collections of selected and edited papers.

IFIP distinguishes three types of institutional membership: Country Representative Members, Members at Large, and Associate Members. The type of organization that can apply for membership is a wide variety and includes national or international societies of individual computer scientists/ICT professionals, associations or federations of such societies, government institutions/government related organizations, national or international research institutes or consortia, universities, academies of sciences, companies, national or international associations or federations of companies.

More information about this series at http://www.springer.com/series/6102 
Julian M. Bass · P. J. Wall (Eds.)

\section{Information}

and Communication

Technologies

for Development

16th IFIP WG 9.4 International Conference on Social Implications of Computers in Developing Countries, ICT4D 2020

Manchester, UK, June 10-11, 2020 Proceedings

粤 Springer 


\title{
Editors
}

\author{
Julian M. Bass \\ University of Salford \\ Salford, UK
}

\author{
P. J. Wall (iD \\ Trinity College Dublin \\ Dublin, Ireland
}

\author{
ISSN 1868-4238 ISSN 1868-422X (electronic) \\ IFIP Advances in Information and Communication Technology \\ ISBN 978-3-030-65827-4 ISBN 978-3-030-65828-1 (eBook) \\ https://doi.org/10.1007/978-3-030-65828-1
}

(C) IFIP International Federation for Information Processing 2020

This work is subject to copyright. All rights are reserved by the Publisher, whether the whole or part of the material is concerned, specifically the rights of translation, reprinting, reuse of illustrations, recitation, broadcasting, reproduction on microfilms or in any other physical way, and transmission or information storage and retrieval, electronic adaptation, computer software, or by similar or dissimilar methodology now known or hereafter developed.

The use of general descriptive names, registered names, trademarks, service marks, etc. in this publication does not imply, even in the absence of a specific statement, that such names are exempt from the relevant protective laws and regulations and therefore free for general use.

The publisher, the authors and the editors are safe to assume that the advice and information in this book are believed to be true and accurate at the date of publication. Neither the publisher nor the authors or the editors give a warranty, expressed or implied, with respect to the material contained herein or for any errors or omissions that may have been made. The publisher remains neutral with regard to jurisdictional claims in published maps and institutional affiliations.

This Springer imprint is published by the registered company Springer Nature Switzerland AG The registered company address is: Gewerbestrasse 11, 6330 Cham, Switzerland 


\section{Preface}

This book presents the collection of papers selected for presentation at the International Federation for Information Processing (IFIP) Working Group 9.4 16th International Conference organized under the banner of the Third European Conference on the Social Implications of Computers in Developing Countries. The conference was hosted in Manchester, UK, by the University of Salford in June 2020.

Research papers published in this volume address ICT-related research challenges in Africa, Asia, and South America, including: Bangladesh, Brazil, Lebanon, Malawi, Myanmar, Nepal, Nigeria, Palestine, South Africa, and Rwanda. Despite being Convened as a European Conference, we were delighted to have facilitated such a global perspective on ICT4D.

We received 29 submissions which were each single-blind peer-reviewed by at least three members of the Program Committee. As a consequence of this process, 14 papers were accepted and selected for presentation at the conference. A further 4 papers were conditionally accepted, subject to refinement using more detailed feedback and advice from reviewers. 10 papers were given detailed feedback but not accepted. The authors of these papers have been encouraged to revise their papers for submission to the next global conference, to be held in Peru during 2021-now postponed to 2022. Sadly, one accepted paper was withdrawn by the authors.

\section{Online Conference}

The conference was initially organized as a face-to-face event, to be hosted by the University of Salford at Media City UK in Greater Manchester. However, the COVID-19 pandemic resulted in the UK Government advice to "Stay at Home," along with many countries imposing their own travel restrictions. Consequently, the University of Salford campus was closed and international travel prohibited. In order to facilitate dissemination of the research already submitted, we migrated to an online event.

One consequence of this was that we had to abandon the planned conference dinner in the Manchester United football ground at Old Trafford. Surprisingly perhaps, this sad turn of events did slightly gratify one group of delegates. The local fans of the nearby Manchester City football club were mildly comforted not to have to celebrate the conference dinner at the competing Manchester United ground!

Football rivalries aside and on a more positive note, we were able to retain the conference keynote speakers and workshops, albeit in abbreviated form. Also, the day before the IFIP WG 9.4 event the ICT4D North group of English Universities also held their annual workshop online. 


\section{Previous Conferences}

The IFIP WG 9.4 First European Workshop on Iterative and Incremental Approaches to ICT4D was held at Robert Gordon University in Aberdeen, UK, in May 2014. The keynote speaker at that workshop was Eswaran Subrahmanian from Carnegie Mellon University, USA.

The second European conference was held in Tirana, Albania, in June 2018, and was organized by IFIP WG 9.4, the UNESCO chair in ICT4D at Royal Holloway, University of London, UK, the European University of Tirana, Albania, and the University of Tirana, Albania.

The IFIP WG 9.4's global conference series has been running for more than 20 years. With the 15th International Conference on Social Implications of Computers in Developing Countries held in Dar es Salaam, Tanzania, in May 2019.

\section{Keynote Speakers}

Despite the condensed online format adopted for the third European conference, we were pleased to welcome keynote speakers: Dr. Ciara Heavin, University College Cork, Ireland, and Terrance Fernando, University of Salford, UK.

Dr. Heavin's keynote talk focused on her work on the IMPACT project in Nigeria between 2016-2018. The key findings from the project included identification of isolated rural social agencies that limited the authority and value of centralized initiatives including public health based initiatives. A further important finding indicated that trained healthcare professionals were scarce and that the public health system relied on distributed and informal communities of practice. She emphasized that this meant existing material agencies of rural healthcare centres were not sufficient for deep enactment of agreed healthcare delivery guidelines.

Prof. Fernando spoke on "Technology Enhanced Adaptive Governance for Building Resilient Cities: Barriers and Challenges." His talk drew on the experience of projects that had attracted over GBP $£ 7 \mathrm{M}$ over a five year period in areas of disaster response management, disaster risk reduction, and risk sensitive urban design. Drawing on his experience of working in Sri Lanka, Pakistan, and Malaysia, he emphasized the importance of developing a culture of collaboration among stakeholders and building sustainable teams to overcome political instability.

\section{Panels}

The first panel addressed "Philosophical Approaches to ICT4D" and was chaired by Dr. Dympna O’Sullivan (Technical University Dublin, Ireland). The panelists were Prof. Sundeep Sahay (University of Oslo, Norway), Dr. David Kreps (University of Salford, UK), and Prof. Silvia Masiero (now with the University of Oslo, Norway). 
This panel discussion critically examined the changing ICT4D landscape from a variety of ontological, philosophical, and methodological perspectives. The discussion spanned a variety of topics including the dominance of positivist and interpretivist approaches in the field, the establishment and rapid growth of the HISP project, and the current move towards more critical realist, Southern-based and other indigenous and regional research paradigms and theories. It was strongly argued that such changed methods and philosophical approaches are necessary in order to address the changing nature of the ICT4D field resulting from increasing use of AI and advanced technologies in the Global South and the growing importance of ethical considerations in this work. It was also agreed that we are witnessing the emergence of a new ICT4D 3.0 digital for development paradigm and new approaches are needed to address this.

Prof. Robert Davison, City University of Hong Kong, Hong Kong, and Dr. Pamela Abbott, The University of Sheffield, UK, facilitated the second workshop on "Academic Publishing for Early Career Researchers." The workshop focused on capacity building for researchers from the Global South, to support them in gaining access to high-quality journals for their ICT4D research. 


\section{Acknowledgements}

We would like to thank the Program Committee members for their support in reviewing and selecting the submissions. We also express gratitude to all our sponsors: the IFIP WG 9.4 (ifipwg94.org), BCS - the Chartered Institute for IT, Manchester Branch, the University of Salford, UK, and the ADAPT Centre, Trinity College Dublin, Ireland.

We also appreciate the support of Prof. Robert Davison who is chair of the IFIP 9.4 WG and Editor-in-chief of the Electronic Journal of Information Systems in Developing Countries. Also, David Kreps, chair of the IFIP Technical Committee 9 on Humans and Computers. Both, not only enabled and supported the event within IFIP, but we were delighted that they attended and contributed to the conference. 


\section{Organization}

\section{Conference and Program Committee Chairs}

Julian M. Bass

P. J. Wall

\section{Program Committee}

Pamela Abbott
Rehema Baguma
Laurence Brooks
Suzana Brown
Jyoti Choudrie
Regina Connolly
Robert Davison
Christopher Foster
Tarek Gaber
G. Harindranath
Andy Haxby
Ciara Heavin
Lucy Hederman
Richard Heeks
Faheem Hussain
Ibrahim Inuwa
Muhammadou Kah
Stan Karanasios
Ebenezer Laizer
Dave Lewis
Arunima Mukherjee
Shirin Madon
Silvia Masiero
Suvodeep Mazumdar
Brian Nicholson
Petter Nielsen
Siwel Nyamba
Dympna O'Sullivan
Scarlet Rahy
Ravishankar M. N.
Jaco Renken
M. A. Setiawan
Mira Slavova
Johan Sæ bo

University of Salford, UK

Trinity College Dublin, Ireland
The University of Sheffield, UK Makerere University, Uganda

De Montfort University, UK

SUNY Korea, South Korea

University of Hertfordshire, UK

Dublin City University, Ireland

The City University of Hong Kong, Hong Kong

The University of Manchester, UK

University of Salford, UK

Royal Holloway, University of London, UK

Competa It B.V., The Netherlands

University College Cork, Ireland

Trinity College Dublin, Ireland

The University of Manchester, UK

Arizona State University, USA

American University of Nigeria, Nigeria

American University of Nigeria, Nigeria

The University of Queensland, Australia

University of Turku, Finland

Trinity College Dublin, Ireland

University of Oslo, Norway

London School of Economics, UK

Loughborough University, UK

The University of Sheffield, UK

The University of Manchester, UK

University of Oslo, Norway

Sokoine University of Agriculture, Tanzania

Technical University Dublin, Ireland

University of Salford, UK

Loughborough University, UK

The University of Manchester, UK

Universitas Islam Indonesia, Indonesia

Warwick Business School, UK

University of Oslo, Norway 
Devinder Thapa

Jean-Paul Van Belle

Fathul Wahid

Tariq Zaman

Chidi Ononiwu

Sundeep Sahay

Wilfred Senyoni
University of Agder, Norway

University of Cape Town, South Africa Universitas Islam Indonesia, Indonesia

Universiti Malaysia Sarawak, Malaysia

American University of Nigeria, Nigeria

University of Oslo, Norway

University of Oslo, Norway 


\section{Contents}

\section{Digital Platforms and Gig Economy}

Competing Logics: Towards a Theory of Digital Platforms

for Socio-economic Development . . . . . . . . . . . . . . . . .

Silvia Masiero and Brian Nicholson

Different Approaches to Complementing Software Platforms:

A Case Study of Digital Innovation Across 10 Developing Countries . . . . . .

Nilza Collinson, Masoud Mahundi, and Petter Nielsen

Risks and Risk-Mitigation Strategies of Gig Economy Workers

in the Global South: The Case of Ride-Hailing in Cape Town . . . . . . . . . . .

Tatenda Mpofu, Pitso Tsibolane, Richard Heeks,

and Jean-Paul Van Belle

\section{Theory and Open Science}

The Potential of Open Science for Research Visibility in the Global South:

Rwandan Librarians' Perspectives . . . . . . . . . . . . . . . . . .

Pamela Abbott and Andrew Cox

Digital Innovation by Displaced Populations: A Critical Realist Study

of Rohingya Refugees in Bangladesh. . . . . . . . . . . . . . . . . . .

Faheem Hussain, P. J. Wall, and Richard Heeks

A Post-colonial Analysis of Agile Software Development Methods

in ICT4D . . . . . . . . . . . . . . . . . . . . . . . . . . . . . . . .

Scarlet Rahy, David Kreps, Julian M. Bass, Tarek Gaber, and Abdulhamid Ardo

\section{Education and Health}

The Adoption of Mobile Health (mHealth) Services by Internally Displaced

Persons (IDPs) in Nigeria. . . . . . . . . . . . . . . . . . . . . . .

Dolapo Bilkis Gbadegesin and Olumide Longe

Embracing uMunthu: How Informal Caregivers in Malawi Use ICTs. . . . . . . Efpraxia D. Zamani and Laura Sbaffi

Constraining and Enabling Factors in the Use of ICT in Rural Schools

in Nepal.

Dhiraj Thapa, Dai Griffiths, and Ann L. Kolodziejski 
Educational Technology as a Positioning Tool in Rural Bangladesh . . . . . . . Taslima Ivy

\section{Inclusion and Participation}

ICT-Based Participation in Support of Palestinian Refugees' Sustainable Livelihoods: A Local Authority Perspective . . . . . . . . . . . . . . . . . Osama Aradeh, Jean-Paul Van Belle, and Adheesh Budree

Appraising WhatsApp in the Indian Context: Understanding the Rural Sentiment. . . . . . . . . . . . . . . . . . . . . . . . . . . . .

Anushruti Vagrani, Saroj Bijarnia, P. Vigneswara Ilavarasan, and Silvia Masiero

Enrolling Actors in a Social Information System: The Incremental Development of Unique Registry in Brazilian "Bolsa Família" Program. . . . . Nadja Piedade de Antonio, Marcelo Fornazin, Renata Mendes de Araujo, and Rodrigo Pereira dos Santos

\section{Business Innovation and Data Privacy}

Exploring Gender Gaps: How Nigerian Micro Business Owners Use

Mobile Apps for Business . . . . . . . . . . . . . . . . . . . . . .

Adebowale Owoseni, Kutoma Wakunuma, Adedamola Tolani, and Hossana Twinomurinzi

What Enables and Restrains Business Entrepreneurship in Refugee Camps in Malawi? A Search for Technology-Related Causal Mechanisms . . . . . . . . Suzana Brown, P. J. Wall, Patience Desire, Dave Lewis, Lucy Hederman, and Chrystina Russell

Check Your Tech - Considering the Provenance of Data Used to Build

Digital Products and Services . . . . . . . . . . . . . . . . . . Dympna O'Sullivan and Damian Gordon

Data Privacy and Protection: The Role of Regulation and Implications for Data Controllers in Developing Countries . . . . . . . . . . . . . . . . Mohammed Agbali, Abubakar A. Dahiru, G. Daniel Olufemi, Inuwa A. Kashifu, and Olatunji Vincent

Implementation of Agile Methodology in Developing Countries:

Case Study in Lebanon . . . . . . . . . . . . . . . . . . . . Scarlet Rahy and Julian M. Bass 